\title{
Optimization of B-Galactosidase Produced by a Potential Lactic Acid Bacteria Lactobacillus casei MB2 Isolated from Traditional Dairy Product of Himachal Pradesh
}

\author{
Heena Chandel and Nivedita Sharma* \\ Microbiology Research Laboratory, Department of Basic Sciences, Dr Y S Parmar University \\ of Horticulture and Forestry, Nauni, Solan-173230, HP, India \\ *Corresponding author
}

\begin{abstract}
A B S T R A C T
Keywords

$\beta$-galactosidase, submerged fermentation, lactic acid bacteria, lactose intolerance

Article Info

Accepted:

20 May 2020

Available Online:

10 June 2020

$\beta$-galactosidase enzyme is commercially important and is generally used in dairy industries for the improvement of lactose intolerance. In this study, different strains of isolated lactic acid bacteria were evaluated for their $\beta$ galactosidase productivity, but Lactobacillus casei MB2resulted with the highest production. Therefore, optimal conditions were determined in submerged fermentation processes by using the "one factor at a time" approach. The optimal cultivation conditions predicated from this method were achieved by using MRS medium on $2^{\text {nd }}$ day, $\mathrm{pH} 7.0$, temperature $30^{\circ} \mathrm{C}$ with inoculum size of $4 \%$, lactose as carbon source, peptone as nitrogen source with $3 \%$ substrate (lactose) concentration, $\mathrm{Mg}^{2+}$ as divalent ions and Tween 20 as surfactant added with an approximate yield of 139.65 $\mathrm{IU} / \mathrm{ml}$ escalating the level of $\beta$-galactosidase production.
\end{abstract}

\section{Introduction}

$\beta$-galactosidase

$(\beta$-D-galactosidegalacto

hydrolase, E.C.3.2.1.23, trivially lactase) is a enzyme that hydrolyze the lactose and it is an important enzyme that has been long accepted for dairy industry. One of the glycosidases, is $\beta$-galactosidase enzyme that are mostly produced by lactobacilli and widely used in dairy industry. The study of $\beta$-galactosidase production from different microorganisms is not new but many of these microbes have not been approved for industrial use because not being recognized as food grade microorganisms by WHO.

Moreover, the yield from studied microorganisms is also low that limits their use for commercial purpose. Therefore, higher production of $\beta$-galactosidase from food grade probiotic microorganisms is highly cherished in industry and thus novel lactic 
acid bacteria producing high level of $\beta$ galactosidase are most sought after globally by researchers.

Lactic acid bacteria (LAB) are considered as good source of enzyme because of their GRAS status. $\beta$-galactosidase from food grade probiotic microorganisms are safe for human use. LAB also plays a significant role in the food fermentation processes. Interest in LAB has increased because of their potential production of $\beta$-galactosidase. Capacity of LAB to produce $\beta$-galactosidase has widened their industrial applications. These $\beta$ galactosidase producing strains of LAB are used for the production of lactose intolerance yoghurt, cheese, acidophilus milk and milk based desserts.

More than $70 \%$ of the world's population suffer from the problem of lactose intolerance and it is caused by the low activity of $\beta$ galactosidase in the mucosa of the small intestine (Nogales and Lopez, 2006). The problem of lactose intolerance is prevalent and thus lactose free dairy products are in high demand in the market to cater the need of lactose intolerant patients. Enzymatic hydrolysis of lactose by $\beta$-galactosidase is one of the most popular technology to produce lactose reduced milk and related dairy products for consumption by lactose intolerant people. Consequently, there is a need for novel lactic acid bacterial isolates that are capable of producing economic quantities of $\beta$-galactosidases with the ability to function efficiently at high or low temperatures.

The objective of our study was to explore the potential of lactic acid bacteria isolated from traditional dairy products of Himachal Pradesh, India and to improve the yield of $\beta$ galactosidase produced from it by optimizing different environmental parameters affecting its activity.

\section{Materials and Methods}

\section{Isolation of lactic acid bacteria}

Different dairy products were collected from Himachal Pradesh for the isolation of $\beta$ galactosidase producing lactic acid bacteria. The serial dilution method was adopted for the isolation.Stock was made from these samples by adding $1 \mathrm{ml}$ of sample in $9 \mathrm{ml}$ of distilled water. All samples were serially diluted by serial dilution in the dilution range of $10^{-1}$ to $10^{-9}$. The samples $(0.1 \mathrm{ml}$ each $)$ from each dilution were mounted by spread plate method on sterilized petri plates containing solidified selected medium viz. de Man, Rogosa and Sharpe (MRS) agar medium (de Man et al., 1960) for lactic acid bacteria. Plates were incubated at $37^{\circ} \mathrm{C}$ for $48 \mathrm{~h}$ under anaerobic conditions. The colonies so obtained were further sub-cultured and pure lines were established and maintained on the same medium.

\section{Screening of isolates for $\beta$-galactosidase production}

\section{Qualitative screening of $\beta$-galactosidase}

$\beta$-galactosidase production was evaluated as described by Lin et al., (1989).

\section{$\beta$-galactosidase activity assay (Miller, 1992)}

$1 \mathrm{ml}$ of bacterial cell pellets were harvested by centrifugation at $9000 \mathrm{rpm}$ for $15 \mathrm{~min}$ and then washed twice with Z-Buffer. Resuspend the bacterial cell pellets in $1 \mathrm{ml}$ of chilled ZBuffer. Absorbance of cell suspension was measured at $600 \mathrm{~nm}$ against Z-buffer. For each reaction mixture, $1 \mathrm{ml}$ of resuspended cells were permeabilized by adding $100 \mu \mathrm{l}$ chloroform and $50 \mu \mathrm{l} 0.1 \%$ SDS. The tubes were vortexed for $30 \mathrm{sec}$ and equilibrated for $5 \mathrm{~min}$ in water bath at $37^{\circ} \mathrm{C}$. The reaction was

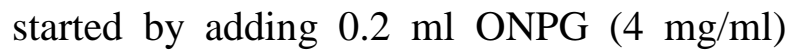


substrate followed by incubation at $37{ }^{\circ} \mathrm{C}$ till the yellow color was appear. The reaction was stopped by adding $0.5 \mathrm{ml}$ of $1 \mathrm{M} \mathrm{Na}_{2} \mathrm{CO}_{3}$ and contents were centrifuged to remove debris and chloroform. OD was recorded at $420 \mathrm{~nm}$ and $550 \mathrm{~nm}$. Miller units for $\beta$-galactosidase were calculated using following formula.

Miller units $=1000 *\left[\mathrm{OD}_{420}-1.75 * \mathrm{OD}_{550}\right] /$ $\mathrm{T} * \mathrm{~V} * \mathrm{OD}_{600}$

where $\mathrm{OD}_{420}$ and $\mathrm{OD}_{550}$ are read from reaction mixture, $\mathrm{OD}_{600}$ is cell density in washed cell suspension, $\mathrm{T}=$ reaction time (min), $\mathrm{V}=$ culture volume $(\mathrm{ml})$ used in assay.

Protein content of culture filtrate was also determined by Folin-Ciocalteu reagent using Bovine Serum Albumin (BSA) standard (Lowry et al., 1951). The best lactic acid bacterial strain showing maximum $\beta$ galactosidase activity without was selected for optimization studies.

\section{Identification of hyper $\beta$-galactosidase producing isolate}

\section{Morphological studies}

Characteristics of selected bacterial colonies were observed according to colony color, elevation, margin and by using differential staining method.

\section{S rRNA technique}

Selected bacterial isolate was further identified at genomic level using $16 \mathrm{~S}$ rRNAtechnique. PCR amplification was done from the genomic DNA by using forward and reverseprimers i.e16SF (5'AGAGTTTGATC CTGGTCA3') and 16SR(5'TACCTTGTT ACGACTT3'). The translated nucleotide sequence was then analyzed for similarities by BLASTN tool (www.ncbi.nim.nih. gov:80/BLAST).
Optimization of process parameters for hyper $\beta$-galactosidase production by one variable at a time (OVAT) approach

Various growth conditions viz. effect of incubation time, inoculum size, temperature, $\mathrm{pH}$, carbon source, nitrogen, divalent cations, best carbon source concentration and surfactants were studied to monitor their effect on $\beta$-galactosidase production.

\section{Effect of incubation time}

Flask containing $50 \mathrm{ml}$ of production medium (i.e MRS agarmedium) were inoculated with $2 \%$ seed culture and incubated at $37^{\circ} \mathrm{C}$ with constant shaking. Following incubation for various time interval $(24,48,72, \ldots, 144 \mathrm{~h})$. The culture was centrifuged at $12,000 \mathrm{rpm}$ for 15-20 min and bacterial pellets were collected and $\beta$-galactosidase activity was assayed by method of Miller, 1992.

\section{Effect of inoculum size}

Culture flasks each containing MRS agar medium were inoculated at a level of $1 \%, 2 \%$, $3 \%, \ldots, 6 \% \quad(\mathrm{v} / \mathrm{v})$. The enzyme was extracted from each set following an incubation of $48 \mathrm{~h}$ at $37^{\circ} \mathrm{C} . \beta$-galactosidase assay was performed to quantify the enzyme.

\section{Effect of pH}

The $\mathrm{pH}$ of optimized media was set at different levels such as 4, 5, 6, 7, 8, 9, 10 and activity of $\beta$-galactosidase was determined after incubation of 2 days at $37^{\circ} \mathrm{C}$ under constant shaking at $120 \mathrm{rpm}$.

\section{Effect of temperature}

Erlenmeyer flask each containing $50 \mathrm{ml}$ of optimized medium was seeded and incubated at a temperature range varying form 25,30 , $35,40,45,50^{\circ} \mathrm{C}$ for 2 days under optimized 
$\mathrm{pH}$ condition. After incubation $\beta$-galactosidase was extracted and assayed.

\section{Effect of different carbon sources}

Various carbon sources including glucose, lactose, maltose, fructose, sucrose and xylose were added in each of the flask containing optimized medium $(50 \mathrm{ml})$. Enzyme production was measured after 2 days at $30^{\circ} \mathrm{C}$ by Miller's method (Miller, 1992).

\section{Effect of substrate concentration}

Erlenmeyer flask each containing $50 \mathrm{ml}$ of optimized medium was seeded with $2 \%$ bacterial culture. The flasks were incubated at $30^{\circ} \mathrm{C}$ at $120 \mathrm{rpm}$ with different lactose concentration ranging from $1 \%$ to $6 \%$. Enzyme production was measured after 2 days at $30^{\circ} \mathrm{C}$ by Miller's method (Miller, 1992).

\section{Effect of different nitrogen sources}

Different nitrogen sources i.e. peptone, beef extract, sodium chloride, ammonium nitrate, sodium nitrate and urea were used at a concentration of $1.0 \%$. All the flasks were incubated at $30^{\circ} \mathrm{C}$ at $120 \mathrm{rpm}$. The enzymes was extracted and assayed for activity on 2 nd day of incubation.

\section{Effect of divalent ions}

Various divalent ions including i.e. $\mathrm{Ca}^{2+}$, $\mathrm{Mg}^{2+}, \mathrm{Cu}^{2+}, \mathrm{Ba}^{2+}, \mathrm{Fe}^{2+}$ and $\mathrm{Zn}^{2+}$ were added in each of the flask containing optimized medium $(50 \mathrm{ml})$. Enzyme production was measured after 2 days at $30^{\circ} \mathrm{C}$ by Miller's method.

\section{Effect of surfactants}

Various detergents like Tween 80, Tween 20, SDS, Gycerol, EDTA and Triton X100were added in optimized medium and their effect on $\beta$-galactosidase production was estimated after incubation at $30^{\circ} \mathrm{C}$ for 2 days under constant shaking conditions. The enzymes was then extracted by centrifugation at 12,000 rpm for 15-20min and assayed for activity by using Miller's Method.

\section{Results and Discussion}

The selected lactic acid bacterial strain MB2 was creamish in color having circular form, raised elevation and entire margin (Plate 1) It was gram positive in nature with bacilli in shape and had been identified as Lactobacillus caseiMB2 using (16S rRNA) PCR technique ( Plate2).

Lactobacillus casei MB2 showing maximum $\beta$-galactosidase activity i.e. $30.15 \mathrm{IU} \mathrm{ml}^{-1}$

\section{Optimization of $\beta$-galactosidase production of Lactobacillus sp.MK4 by using one variable at a time (OVAT) approach}

\section{Effect of incubation period}

$\beta$-galactosidase activity was measured at regular intervals from $24 \mathrm{~h}$ to a period of 144 h. For LactobacilluscaseiMB2, maximum $\beta$ galactosidase activity of $32.39 \mathrm{IU} / \mathrm{ml}$ was noticed at $48^{\text {th }} \mathrm{h}$ with a specific activity of $154.23 \mathrm{IU} / \mathrm{mg}$ (Fig 1).For Lactobacillus caseiMB2, initial incubation period of $24 \mathrm{~h}$ have resulted in a lesser enzymatic activity of $25.52 \mathrm{IU} / \mathrm{ml}$.Standard error of mean and critical difference has been given in the end of the table.

\section{Effect of inoculum size}

The size of inoculum plays an important role in the fermentation of enzymes. Different inoculum sizes studied for enhanced enzyme production were $1.0,2.0, \ldots, 6.0 \%(\mathrm{v} / \mathrm{v})$. Fig2 reveals the effect of inoculum size on enzyme 
production by Lactobacillus casei MB2. Highest $\beta$-galactosidase titres of $63.25 \mathrm{IU} / \mathrm{ml}$ from $L$. casei $\mathrm{MB} 2$ were observed at $4 \%$ inoculum size. The $\beta$-galactosidase production was constantly increases from $2 \%$ to $4 \%$ inoculums size.

Maximal enzyme activity at optimal level was observed because at this point there is average number of cells which are highly active for maximal production of $\beta$-galactosidase. The decline in enzyme yield at larger inoculum size might be due to formation of thick suspensions and improper mixing of substrates in shake flasks.

\section{Effect of pH}

Enzyme activity is markedly affected by $\mathrm{pH}$. The effect of $\mathrm{pH}$ is crucial in terms of growth of the producing organism and the biosynthesis of $\beta$-galactosidase. The $\mathrm{pH}$ of the growth medium plays an important role in terms of inducing enzyme production and morphological changes in the microbes (Pederson and Nielson, 2000; Kathiresan and Manivannan, 2006).

Keeping in view its importance, the effect of $\mathrm{pH}$ in the range of 5.0-10.0 was evaluated on $\beta$-galactosidase production. Fig 3 represents the effect of $\mathrm{pH}$ on the enzyme production potential from Lactobacillus caseiMB2.

L. caseiMB2 showed maximum enzyme activity of $63.15 \mathrm{IU} / \mathrm{ml}$ was observed at $\mathrm{pH}$ 7.0 with a specific activity of $203.70 \mathrm{IU} / \mathrm{mg}$. At $\mathrm{pH} 5.0$ and 6.0, $\beta$-galactosidase activity of $42.24 \mathrm{IU} / \mathrm{ml}$ and $54.37 \mathrm{IU} / \mathrm{ml}$ respectively was observed. Above optimum, pH 10.0 showed a dipped $\beta$-galactosidase activity of $32.28 \mathrm{IU} / \mathrm{ml}$.

Changes in the external $\mathrm{pH}$ alter the ionization of nutrient molecules and reduce their availability to the organism thus lowering their overall metabolic activity (Willey et al., 2008).

\section{Effect of temperature}

The fermentation temperature appeared to have a dramatic effect on $\beta$-galactosidase MB2 production. L. casei produced maximum $\beta$-galactosidase activity (78.97IU/ml) at temperature of $30^{\circ} \mathrm{C}$, while displaying minimum activity at $30^{\circ} \mathrm{C}(27.55 \mathrm{IU} / \mathrm{ml})$ as is depicted in Fig 4.

Any temperature beyond the optimum range is found to have some adverse effects on the metabolic activities of the microorganisms and it is also reported by various scientists that the metabolic activities of the microbes become slow at lower or higher temperatures (Okolo et al., 1995).

\section{Effect of various carbon sources}

Carbon source in the form of either monosaccharides or polysaccharides influence the production of $\beta$-galactosidase. $\beta$ galactosidase is an inducible enzyme and is generally induced in the presence of lactose. Perusal of the Fig5 revealed that Lactobacillus casei MB2 exhibited highest $\beta$ galactosidase activity of $102.52 \mathrm{IU} / \mathrm{ml}$ with lactose as a carbon source with a specific activity of $277.08 \mathrm{IU} / \mathrm{mg}$. Other carbon sources such as glucose, maltose and sucrose failed to significantly induce $\beta$-galactosidase production.

On the basis of catabolic repression with intracellular accumulation of glucose byproducts and the fact that bacteria primarily consume simple sugars, thus does not induce significant $\beta$-galactosidase production (Murad et al., 2011). $\beta$-galactosidase production was induced by the presence of lactose as a carbon source yielding $102.52 \mathrm{IU} / \mathrm{ml}$ enzyme. 


\section{Effect of substrate concentration (\%)}

Besides the nature of carbon sources in the culture media, the amount of it proved to be equally important from the aspect of the $\beta$ galactosidase production (Ismail et al., 2010). Varying concentrations of the best substrate i.e. lactose for $L$. case $\mathrm{MB} 2$ ranging from 1.0 to $6.0 \%$ were explored for its effect on the enzyme yield. The results have been given in Fig6.

L. case $\mathrm{MB} 2$, an induction in $\beta$-galactosidase production at 3\% lactose concentration was observed with yield of $125.82 \mathrm{IU} / \mathrm{ml}$ and specific activity $314.55 \quad \mathrm{IU} / \mathrm{mg}$. $\beta$ galactosidase is lactose inducible enzyme and its activity yield represents a compromise between lactose induction and intracellular glucose repression.

There were statistical significant variations among the different substrate concentrations used for $\beta$-galactosidase production ranging from $1.0-6.0 \%$. Very low substrate concentration fails to trigger enzyme production to desirable level because most of the inoculum remains without substrate and hence resulting in minimum secretion of enzymes. Optimum substrate concentration normally results in an increase in the yield and reaction rate of the hydrolysis (Regina $e t$ al., 2008). However, high substrate concentration causes substrate inhibition, which substantially lowers enzyme production (Liu and Yang, 2007; Singhania et al., 2007). An increase in substrate concentration from optimum upto $6.0 \%$ has resulted in decreased $\beta$-galactosidase activity.

\section{Effect of various nitrogen sources}

Nitrogen sources are the most important secondary energy compounds for the growth and metabolism of microorganisms. The nature of these compounds and the concentration used may stimulate or down regulate the production of enzymes (Sharma and Singh, 2014). Fig 7 represents the effect of nitrogen sources on $\beta$-galactosidase production by $L$. case $i \mathrm{MB} 2$. L. case $i \mathrm{MB} 2$ enzyme production medium supplemented with peptone showed an increased enzyme activity of $126.24 \mathrm{IU} / \mathrm{ml}$ (specific activity of $315.60 \mathrm{IU} / \mathrm{mg}$ ). The other nitrogen sources used viz. beef extract, sodium chloride, sodium nitrate, ammonium nitrate and urea however showed a decline in enzyme activity.

\section{Effect of divalent ions}

Enzyme action is specific to the presence or absence of a particular metal ion. Likewise, $L$. caseiMB2 exhibited quite a variable behaviour towards $\beta$-galactosidase secretion in the presence of various metal ions in the production medium. As metal ions accept or donate electrons and act as electrophiles, mask nucleophiles to prevent unwanted side reactions, bind enzyme and substrate by coordinate bonds, hold the reacting groups in the required 3D orientation, and simply stabilize a catalytically active conformation of the enzyme (Palmer, 2001). Most of the enzymes are metalloenzymes by nature and exhibit an increased activity in the presence of metal ions.Fig8 represent the effect of various metal ions on $\beta$-galactosidase production by L. casei $\mathrm{MB} 2$

\section{Effect of surfactants}

Surfactants in the fermentation medium are known to increase the secretion of proteins by increasing cell membrane permeability (Hashemi et al., 2010). Therefore, addition of these surfactants is used for the production of enzymes (Sivaramakrishnan et al., 2006). Most organisms are stimulated to increased enzyme production; however, enzyme production by some organisms is only slightly affected in the presence of surfactants. 
The increase was less pronounced in the organisms which are normally good producers of the enzyme (Reese and Maguire, 1969). Fig-9 represent the effect of surfactants on $\beta$ galactosidase production by $L$. caseiMB2. All the surfactants resulted in considerable by slightly enhancing the enzyme activity to varying extents. $\beta$-galactosidase production by $L$. caseiMB2 also showed the same trend with the addition of surfactants such as Tween 20. With Tween 20 in the medium, enzyme activity was observed as $139.65 \mathrm{IU} / \mathrm{ml}$ with a specific activity of $332.50 \mathrm{IU} / \mathrm{mg}$ protein.

The maximum production of $\beta$-galactosidase was observed in the medium containing Tween 20 and minimum production was observed in the medium containing SDS and rest were found significantly different.

Classical approach i.e. one variable at a time (OVAT) used for optimization of $\beta$ galactosidase production from L. caseiMB2 has resulted in statistically significant increase in the production of $\beta$-galactosidase.

\section{Discussion}

El Kader et al., (2012) optimized the incubation time for maximum production of $\beta$-galactosidase by $B$. subtilis was at $48 \mathrm{~h}$ and observed that prolonged incubation time beyond this period did not increase the enzyme yield. They observed a maximum $\beta$ galactosidase activity of $440 \mathrm{IU} / \mathrm{ml}$ at stationary phase of $B$. subtilis. The $\beta$ galactosidase activity production exhibited a similar trend as the cell concentration curve and increased gradually as the fermentation started, reaching the maximum activity i.e. $0.781 \mathrm{IU} / \mathrm{ml}$ by L. acidophilus after incubation of $48 \mathrm{~h}$ (Carevic et al., 2015).

In literature, inoculum size of $2 \%$ has been reported optimum for $\beta$-galactosidase production from L. plantarum (Khusniati et al., 2015). Ahmed et al., (2016) reported an enzyme activity of $91.49 \mathrm{IU} / \mathrm{ml}$ from Lactobacillus sp. KLSA 22 at an inoculum size of $1 \%$. A higher inoculum size of $4 \%$ has been reported by $\mathrm{Lu}$ et al., (2010) for $\beta$ galactosidase production by Enterobacter cloacae B5 yielding $14.964 \mathrm{IU} / \mathrm{ml}$ of enzyme.

There are several reports available in the literature regarding the production of $\beta$ galactosidase at neutral $\mathrm{pH}$. Princely et al., (2013) reported $\beta$-galactosidase production from Streptococcus thermophilus producing $\beta$-galactosidase at $\mathrm{pH}$ 7.2. Ahmed et al., (2016) reported the maximum $\beta$-galactosidase production of $89.94 \mathrm{IU}$ at $\mathrm{pH} 6.5$ from Lactobacillus sp. KLSA 22.

Devi et al., (2011) isolated Lactobacillus sp. from curd and yielded $86 \mathrm{IU} / \mathrm{ml}$ at $35^{\circ} \mathrm{C}$. In accordance to our findings, Murad et al., (2011) reported $\beta$-galactosidase production at $30^{\circ} \mathrm{C}$ by Lactobacillus strain isolated from different dairy sources. Lactobacillus sp. KLSA 22 isolated from milk by Ahmed et al., (2016) yielded $90.05 \mathrm{IU} / \mathrm{ml}$ enzyme at $35^{\circ} \mathrm{C}$. $B$. subtilis reported the maximum $\beta$ galactosidase at $35^{\circ} \mathrm{C}$ (Natarajan et al., 2012).

Lactose has also been found to increase enzyme production in L. acidophilus ATCC 4356, L. plantarum B110 and Lactobacillus sp. as reported by Carevic et al., (2015); Khusniati et al., (2015) and Devi et al., (2011) respectively. Other carbon sources viz. sucrose, maltose, fructose and xylose did not result in a considerable $\beta$-galactosidase induction. $\beta$-galactosidase production is subjected to catabolite repression by glucose and other sugars, like most other inducible enzymes.

Several workers have optimized substrate concentrations for efficient $\beta$-galactosidase production. Devi et al., (2011) however reported $7.0 \%$ lactose as optimum for $\beta$ - 
galactosidase production from Lactobacillus sp. Perusal of these results revealed that potential $\beta$-galactosidase producing strains Lactobacillus sp. MK4 and L. caseiMB2 yielding $115.63 \mathrm{IU} / \mathrm{ml}$ and $125.82 \mathrm{IU} / \mathrm{ml}$ respectively of $\beta$-galactosidase at $5.0 \%$ and $3.0 \%$ substrate concentration are potential for hyper $\beta$-galactosidase production and for their effective use in dairy industries. Further increase of lactose concentration upto $10 \%$ dramatically decreased the $\beta$-galactosidase production.

The presence of more than one nitrogen source in the medium has been reported to give better results which are evident from the results of the experiment. Yeast extract has been shown to induce $\beta$-galactosidase production by several workers Devi et al., (2011); Nataranjan et al., (2012); Ismail et al., (2010) for Lactobacillus sp., Bacillus sp. and L. acidophilus, respectively.

$\mathrm{Ca}^{2+}$ and $\mathrm{Mg}^{2+}$ have been reported to enhance enzyme activity by Chanalia et al., (2018); Carevic et al., (2017) and Ustok et al., (2010) from Pediococcus acidilacti, L. acidophilus and Bacillus sp. respectively. Catalytic activity and stability of $\beta$-galactosidase have been reported to be magnesium dependent. Ahmed et al., (2016) reported maximum $\beta$ galactosidase production in the presence of $0.1 \% \mathrm{MgSO}_{4}$ from Lactobacillus sp. KLSA 22.

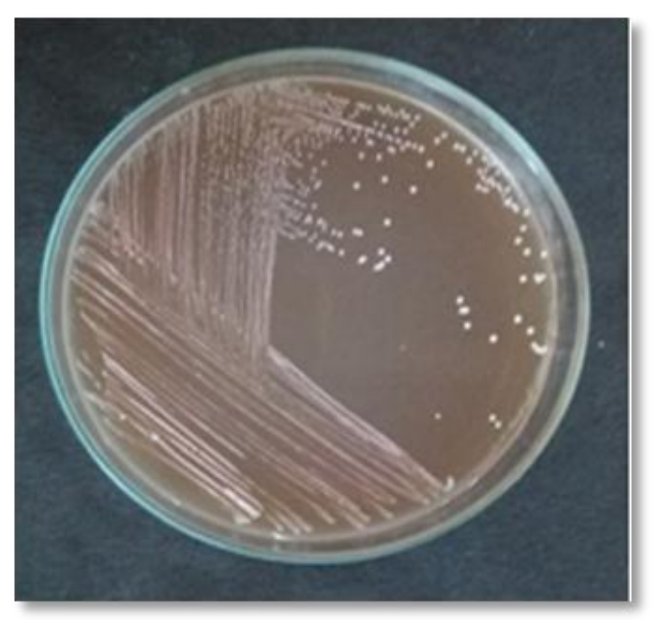

Plate.1 Morphological characteristics of MB2

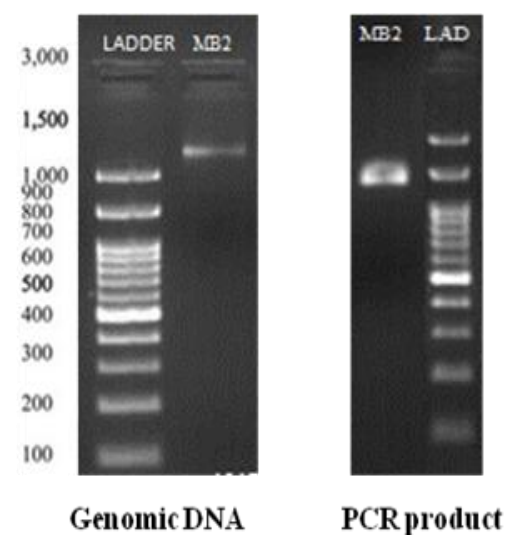

Plate. 2 Molecular identification of hyper $\beta$-galactosidase producing lactic acid bacteria by $16 \mathrm{~S}$ rRNA gene technique 


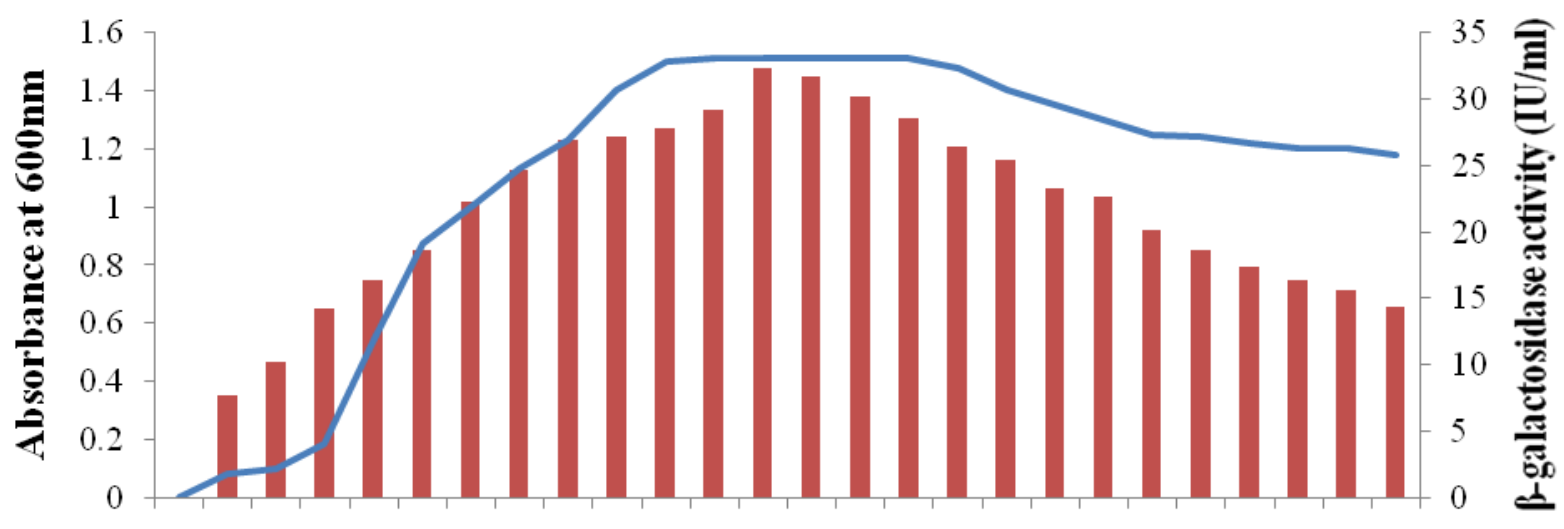

$0 \quad 4 \quad 8 \quad 1216202428323640444852566064687276808488929496$

Time (in hours) $\quad \beta$-galactosidase activity (IU/ml)

Fig.1 Growth cycle of hyper $\beta$-galactosidase producing lactic acid bacteria of L. casei MB2

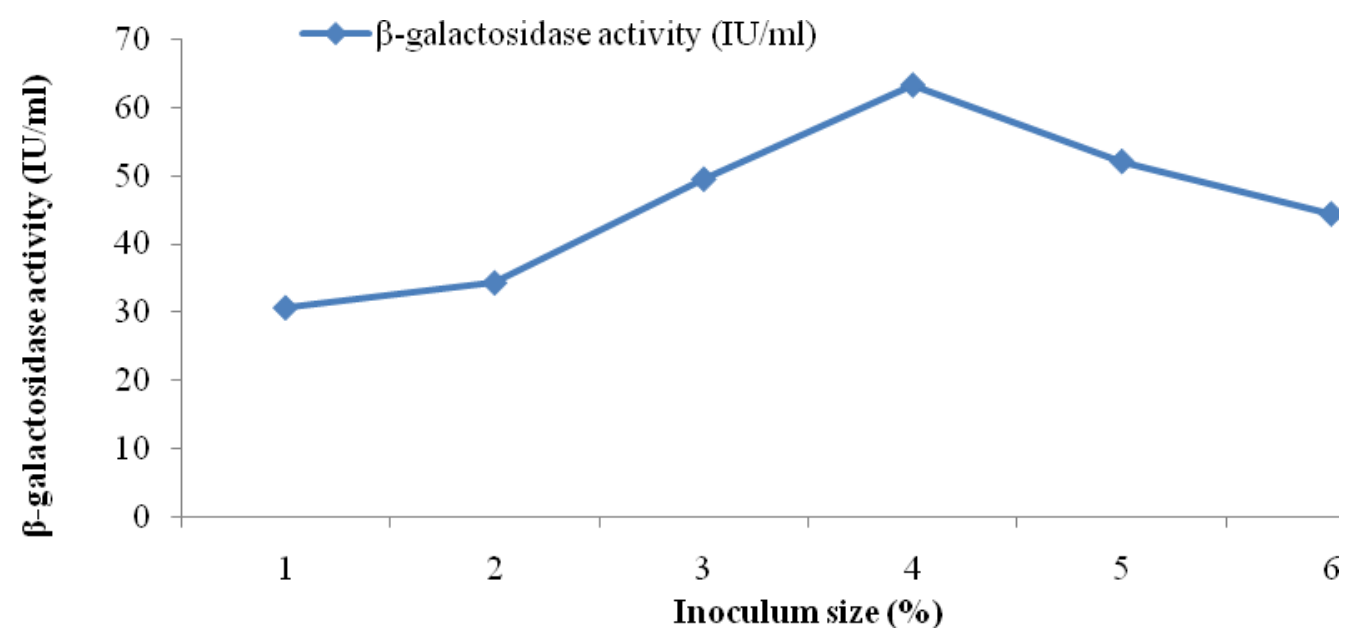

Fig.2 Effect of inoculum size on $\beta$-galactosidase production by L. casei MB2

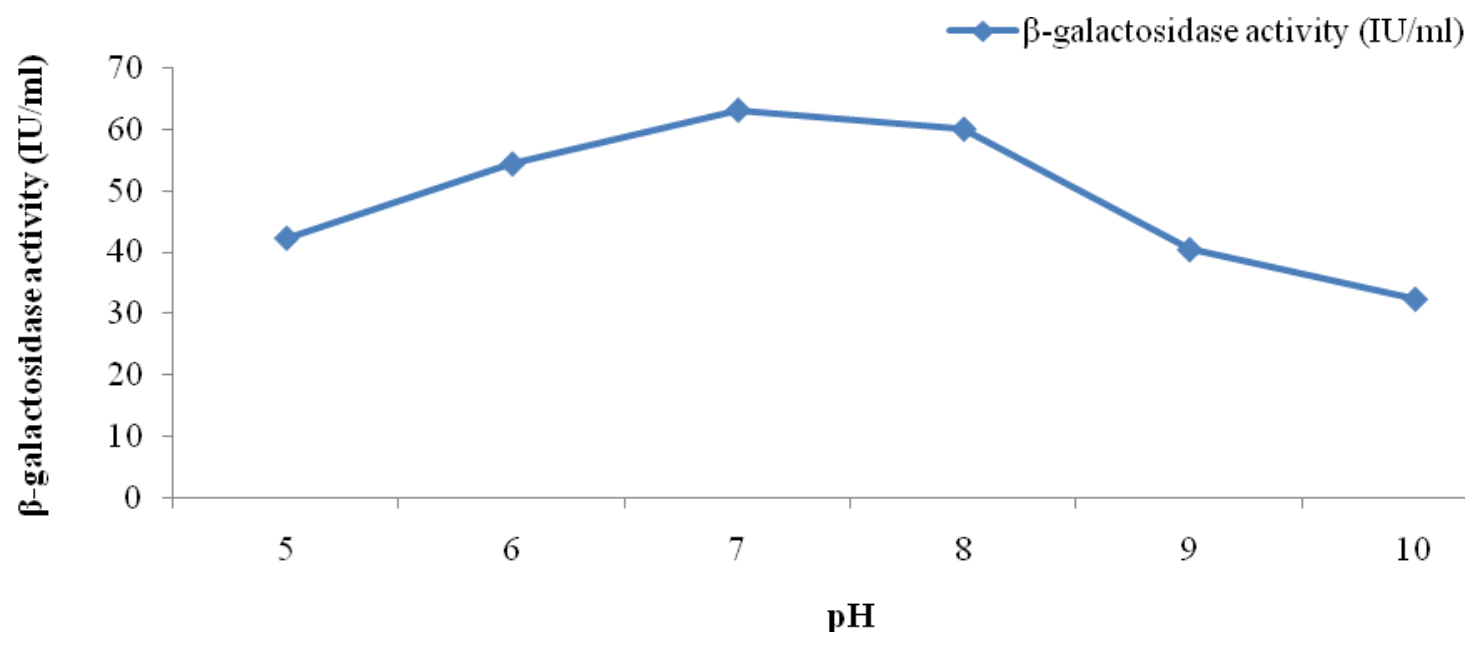

Fig.3 Effect of $\mathrm{pH}$ on $\beta$-galactosidase production by L. casei MB2 


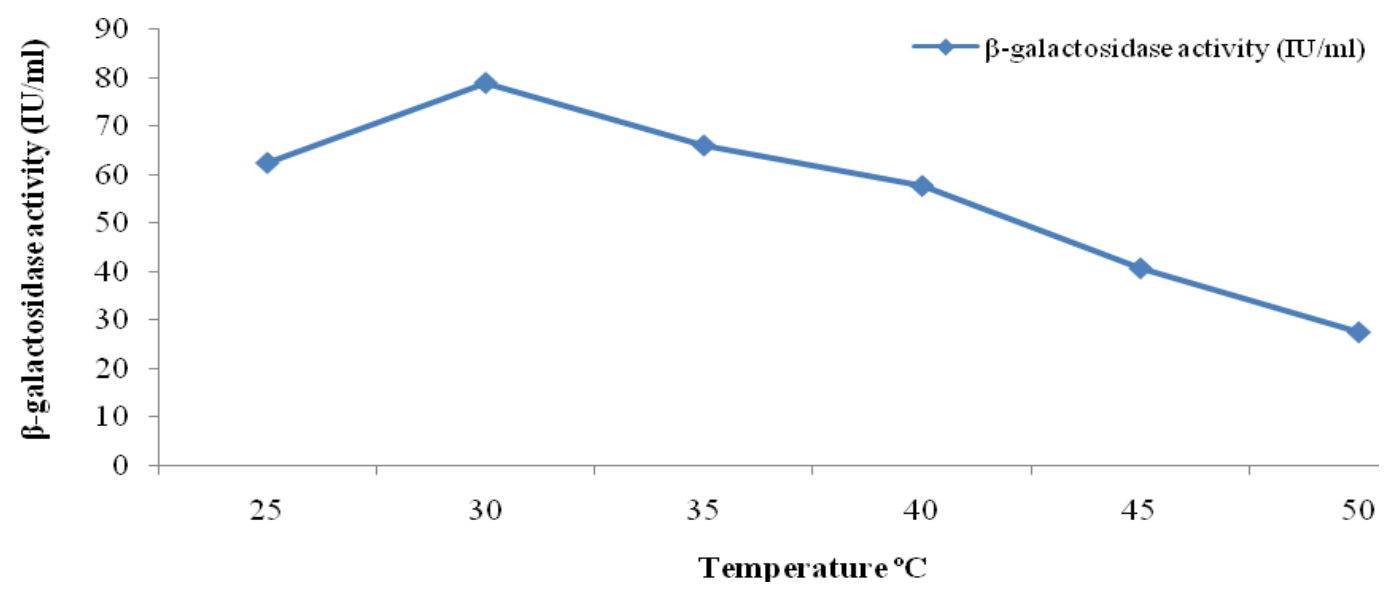

Fig.4 Effect of different temperature on $\beta$-galactosidase production by L. casei MB2

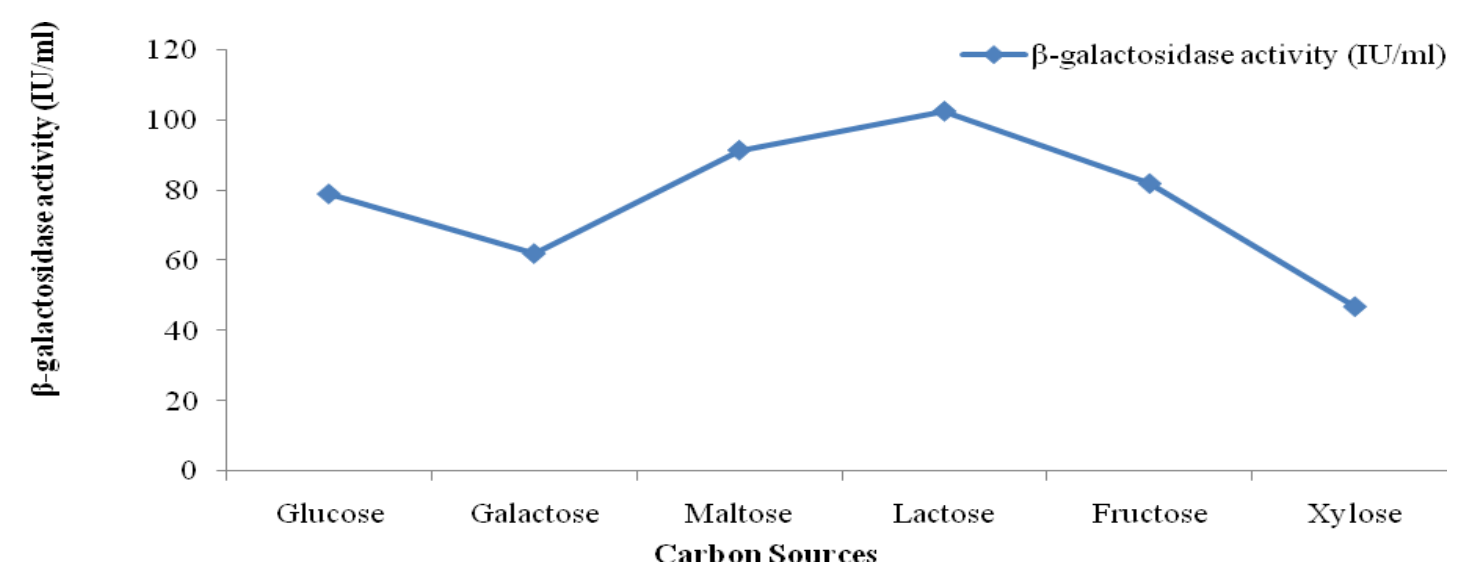

Fig.5 Effect of different carbon sources on $\beta$-galactosidase production by $L$. casei MB2

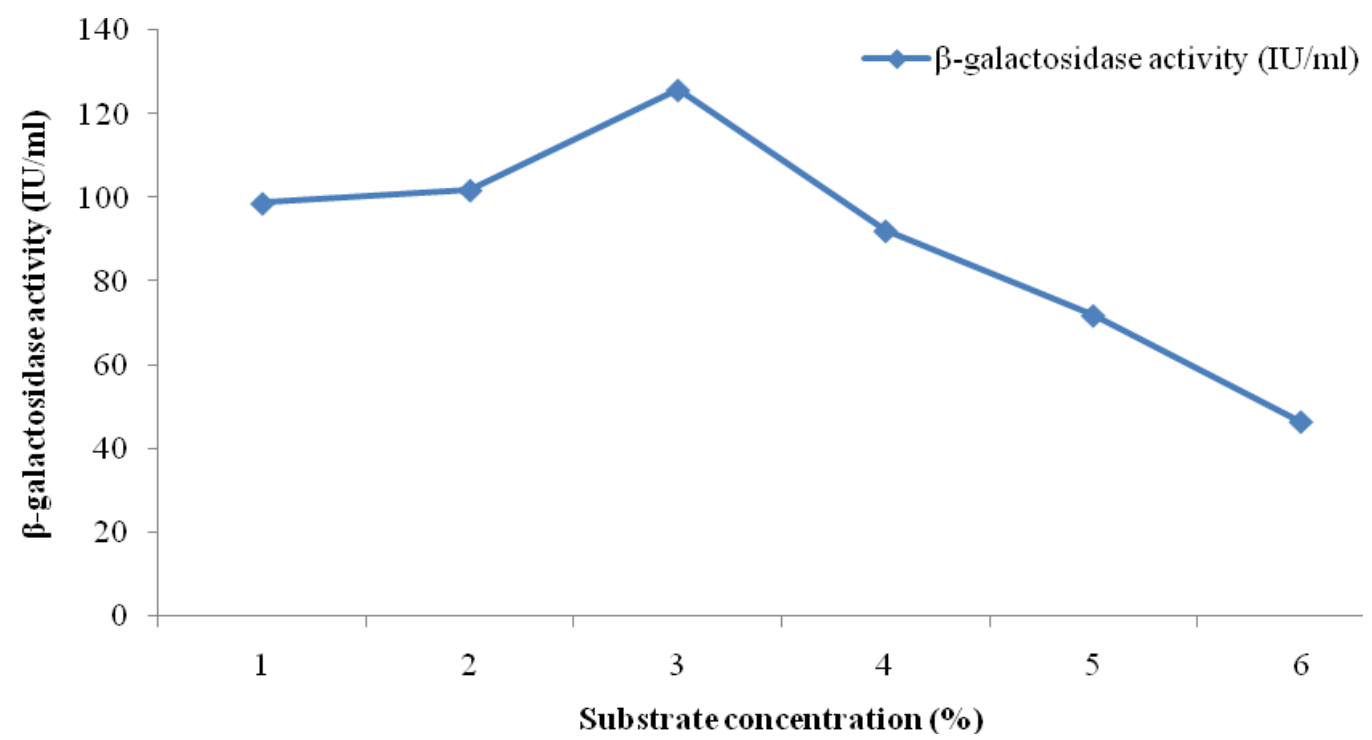

Fig.6 Effect of substrate concentration on $\beta$-galactosidase production by L. casei MB2 


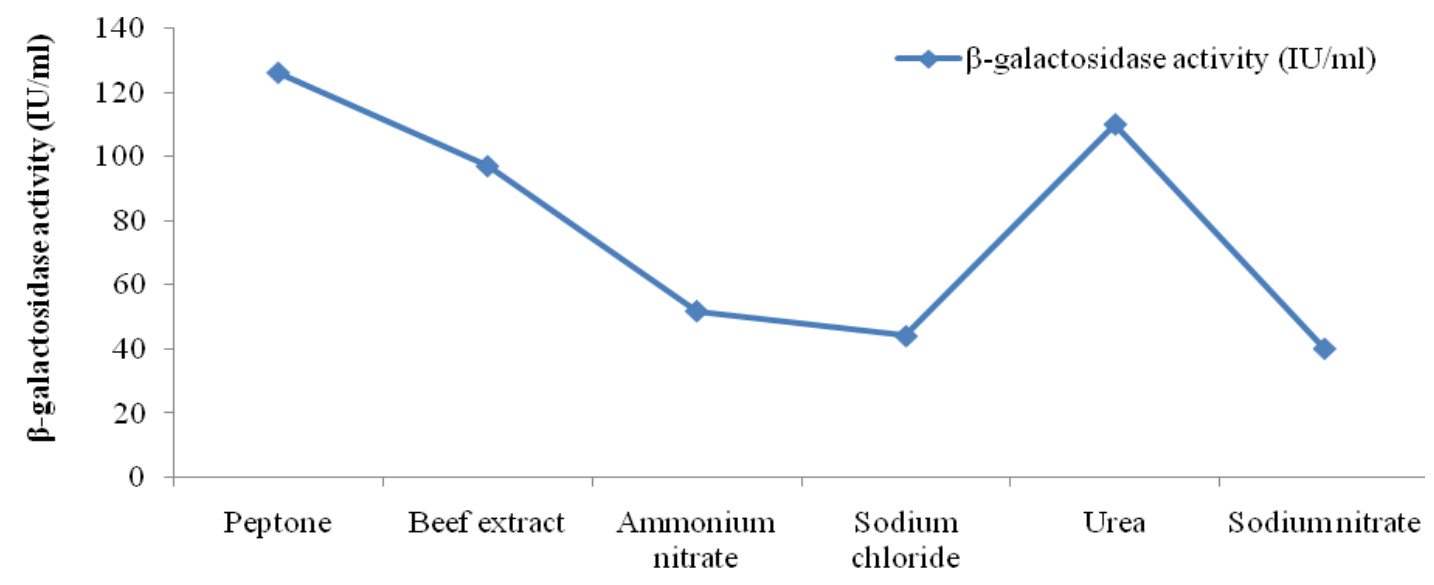

Nitrogen Sources

Fig.7 Effect of different nitrogen sources on $\beta$-galactosidase production by $L$. casei MB2

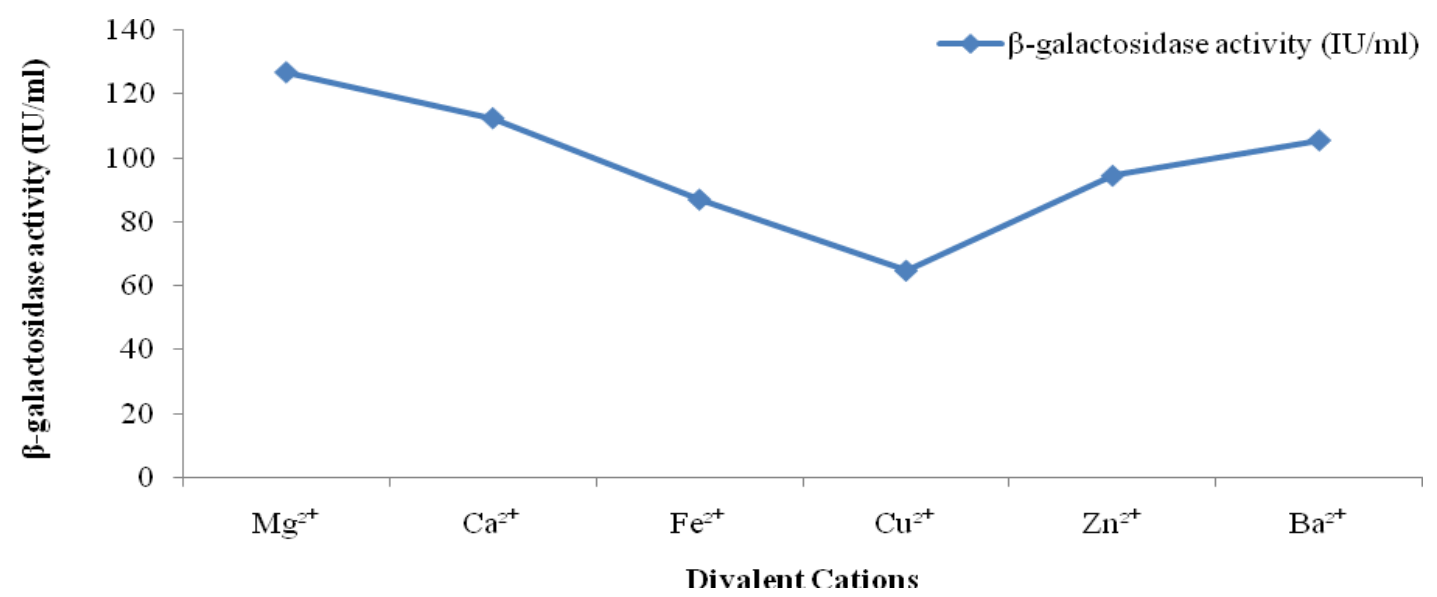

Fig.8 Effect of divalent ions on $\beta$-galactosidase production by L. casei MB2

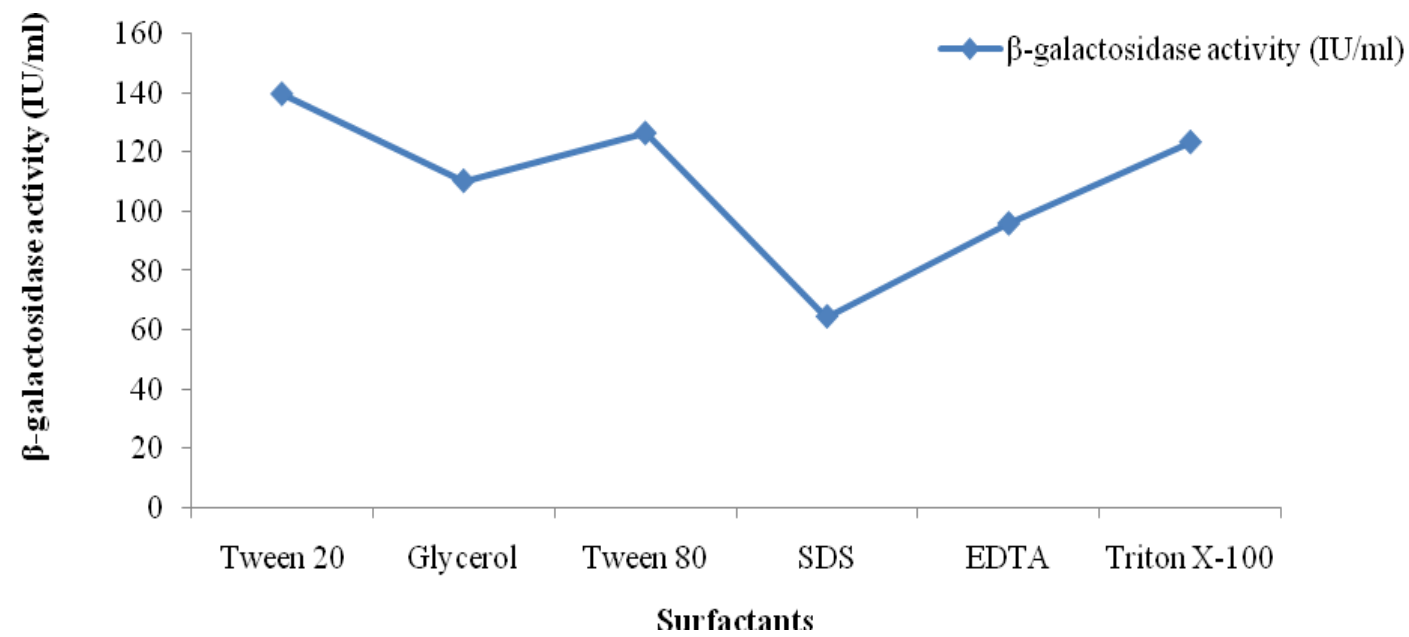

Fig.9 Effect of surfactants on $\beta$-galactosidase production by L. casei MB2 
An increase in enzyme activity on addition of surfactants in the medium has been reported by Rao and Satyanarayana (2007) and Sodhi et al., (2005). However the addition of SDS and EDTA in the medium resulted in inhibition of $\beta$-galactosidase. EDTA had no effect on enzyme activity. Contrarily EDTA inactivated the $\beta$-galactosidase of Lactobacillus plantarum (Iqbal et al., 2010). Tween 20, Triton X-100 and glycerol slightly increases the enzyme activity considerably thus were added in the medium.

\section{Acknowledgement}

The authors are very thankful to the Department of Basic Sciences, Microbiology section, UHF, Nauni, Solan for providing laboratory facilities and to everyone who contributed to the fulfillment of this study.

\section{References}

Ahmed Sarfaraz, Kattimani Lingappa, Divatar Mahesh, Gajare Sandhya, Shivalee A, Asma Farheen. and MasarathIrfana (2016). Optimization of Lactase Production under Submerged Fermentation by Lactobacillus sp. KLSA 22. Int. J. Pure App. Biosci.4:212-220

Carevic M, Vukasinovic-Sekulic M, Grbavcic S, Stojanovic M, Mihailovic M, Dimitrijevic A and BezbradicaD (2015) Optimization of $\beta$-galactosidase production from lactic acid bacteria. Hem. Ind.69:305-12.

Chanalia P, Gandhi D, Attri P and Dhanda S (2018) Purification and characterization of $\beta$-galactosidase from probiotic Pediococcus acidilactici and its use in milk lactose hydrolysis and galactooligosaccharide synthesis. Bioorg. Chem. 77:176-89.

De MJC, Rogosa M and Sharpe ME 1960. A medium for the cultivation of lactobacilli. J. Appl. Bacteriol. 23:1303.

Devi MC, Meera NS, Theja PC and Gopal DV(2011) Production and optimization of $\beta$ - galactosidase enzyme from probiotic Lactobacillus sp. Biotechnol. Adv. 6:153-59.

El-Kader Amal Said Shahat Abd, El-Dosouky Mohammad Ali, Abouwarda Ahmed, Abdel Said Mohammad and Osman Mohammad Ibraheim (2012) Isolation, Screening, Identification and Optimization of Cultural Conditions for Selected Local Bacterial $\beta$ Galactosidase Producer. J. Appl. Sci. Resech.4:2010-17.

Hashemi M, Razavi SH, Shojaosadati SA, Mousavi SM, Khajeh K and Safari M. (2010). Development of solid-state fermentation process for production of an alpha amylase with potentially interesting properties. J BiosciBioeng. 110:333-37.

Iqbal S, Nguyen T, Nguyen TT and Maischberger $T(2010) \quad \beta$-galactosidase purified from Lactobacillus plantarum WCFS1: biochemical characterization and formation of prebiotic glactoologosaccharides. Carbohydr Res. 345:1408-16.

Ismail S A, El-Mohamady Y, Helmy W A, Abou-Romia and Hashem A M (2010) Cultural condition affecting the growth and production of $\beta$-galactosidase by Lactobacillus acidophilus NRRL 449. Aust. J. Basic and Appl. Sci.4:5051-58. Kathiresan K and Manivannan S (2006) $\alpha$ amylase production by $P$. fellutanum isolated from mangrove rhizospheric soil. Afr. J. Biotechnol. 5:829-32.

Khusniati T, Aditya AT, Choliq A and Sulistiani. (2015). Characterization and identification of the best screened indigenous lactic acid bacteria producing $\beta$-galactosidase. Res J Biotechno. 12:439-45. 
Lin WJ, Savaiano DA and Harlander SK (1989) A method for determining $\beta$ galactosidase activity of yogurt cultures in skim milk. J. Dai. Sci.72:351-358.

Liu J and Yang J (2007) Cellulase production by Trichoderma koningii A83.4262 in solid state fermentation using lignocellulosic waste from the vinegar industry. Food Technol Biotech 45:42025.

Lowry $\mathrm{OH}$, Rosebrough NJ, Farr AL and RJ(1951) Protein measurement with Folin Phenol reagent. J. Bio. Chem.193:265-75.

Lu L, Xu X, Gu G, Jin L, Xiao M and Wang $F(2010)$ Synthesis of novel galactose containing chemicals by $\beta$-galactosidase from Enterobacter cloacae B5. Bio Tech. 17:6868-72.

Miller JH (1992) A short course in bacterial genetics: a laboratory manual and handbook for Escherichia coli and related bacteria. Trends Biochem Sci. 18:193-02.

Murad HA, Refaea RI and Aly EM(2011) Utilization of UF-permeate for production of $\beta$-galactosidase by lactic acid bacteria. Pol J Microbiol. 60:13944.

Natarajan J, Christobell C, Kumar DJ, Balakumaran MD, Kumar $\mathrm{M}$ and Kalichelvan PT (2012) Isolation and characterization of $\beta$ - galactosidase producing Bacillus sp. from dairy effluent. World J. Microbiol. Biotechnol. 17:1466-74.

Nogales JMR and Lopez AD (2006) A novel approach to develop $\beta$-galactosidase entrapped in liposomes in order to prevent an immediate hydrolysis of lactose in milk. J. Dairy Sci. 16:354-60.

Okolo BN, Ezeogu LI and Mba CN (1995) Production of raw starch digesting amylase by Aspergillus niger and Bacillus alvei grown on native starch sources. Journal of the Science of Food and Agriculture 69:109-15.

Palmer T (2001) Enzymes: Biochemistry, Biotechnology and Chemical Chemistry, Horwood Publication, Chichester, UK.

Pederson H and Nielson J (2000) The influence of nitrogen sources on the alpha amylase productivity of Aspergillus nigerin continues cultures. Appl. Micro. Biotech3:278-81.

Prasad LN, Ghosh BC and Shah NP (2013) Extraction and characterization of $\beta$ galactosidase produced by Bifidobacterium animalis subsp. lactis Bb12 and Lactobacillus delbrueckii subsp. bulgaricus ATCC11842 grown in whey. Int. Food Res. J.20:487-94.

Princely S, Basha NS. And Kirubakaran JJ(2013) Biochemical characterization, partial purification and production of an intracellular beta-galactosidase from Streptococcus thermophilus grown in whey. Euro J Exp Bio3:242-51.

Rao JL and Satyanarayana T(2007) Purification and characterization of a hyperthermostable and high maltogenic $\alpha$-amylase of an extreme thermophile Geobacillu sthermoleovorans. Biotechnol. Appl. Biochem.142:179-93.

Reese ET and Mguire A (1969) Surfactants as stimulants of enzyme production by microorganisms. Appl. Micro.17:27383.

Regina M, Broetto F, Giovannozzi-Sermanni, Marabatini $\mathrm{R}$ and Peranni $\mathrm{C}$ (2008)Influence of stationary and bioreactor cultivation on Lentinula edodes(bark) Pegler lignocellulolytic activity. Braz Arch Biol Technol 51:223-33

Sharma S and Singh P (2014) Isolation and characterization of $\beta$-Galactosidase enzyme producing microbe and optimization of its enzyme activity under different culture condition. Int $\mathbf{J}$ Cur Micro Appl. Sci.3:148-55. 
Singhania RR, Sukumaran RK and Pandey A (2007)Improved cellulase production by Trichoderma reesei RUTC30 under SSF through process optimization. Appl. Biochem Biotech.142:60-70.

Sivaramakrishnan S, Gangadharan D, Nampoothiri KM, Soccol CR. and Pandey A. (2006). $\alpha$-amylases from microbial sources-an overview on recent developments. F Tech. Biotech.44:173-84.

Sodhi HK, Sharma K, Gupta JK. and Soni SK(2005) Production of a thermostable $\alpha$-amylase from Bacillus sp. PS-75 by solid state fermentation and its synergistic use in the hydrolysis of malt starch for alcohol production. $\mathrm{P}$ Biochem.40:525-34.

Ustok FI, Tari C and Harsa S (2010) Biochemical and thermal properties of $\beta$-galactosidase enzymes produced by artisanal yoghurt cultures. F Chemi. 113:1114-20.

Willey JM, Sherwood LM and Woolverton C J. 2008. Prescott. Harley and Kleins Microbiology, $7^{\text {th }}$ Edn., McGraw Hill Co. Inc., Boston.

\section{How to cite this article:}

Heena Chandel and Nivedita Sharma. 2020. Optimization of B-Galactosidase Produced by a Potential Lactic Acid Bacteria Lactobacillus casei MB2 Isolated from Traditional Dairy Product of Himachal Pradesh. Int.J.Curr.Microbiol.App.Sci. 9(06): 2819-2832. doi: https://doi.org/10.20546/ijcmas.2020.906.341 